\title{
The Effect Of Motor Vehicle Tax Services On Taxpayer Satisfaction In The Samsat Of Bengkulu City
}

\section{Pengaruh Pelayanan Pajak Kendaraan Bermotor Terhadap Wajib Pajak Di Kantor Samsat Kota Bengkulu}

\author{
Atika Puspita Sari ${ }^{1}$ ); Karona Cahya Susena2); Rinto Noviantoro ${ }^{3)}$ \\ 1,3) Department of Accounting, Faculty of Economic, Universitas Dehasen Bengkulu \\ 2) Department of Management Faculty of Economic, Universitas Dehasen Bengkulu \\ Email: atikafusviyta@gmail.com
}

\begin{abstract}
How to Cite:
Puspita Sari A.(2021 The Effect Of Motor Vehicle Tax Services On Taxpayer Satisfaction In The Samsat Of Bengkulu City. Jurnal Ekonomi Manajemen Akuntansi Dan Keuangan, 3(1). DOI: https://doi.org/10.53697/emak.v3i1
\end{abstract}

\section{ARTICLE HISTORY}

Received [1 Desember 2021]

Revised [10 Desember 2021]

Accepted [28 Desember 2021]

\section{KEYWORDS}

Bengkulu City Samsat, service, taxpayer satisfaction

This is an open access article under the CC-BY-SA license

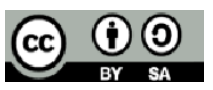

\section{ABSTRAK}

Dalam hal meningkatan Kualitas Pelayanan dan Kepuasan Wajib Pajak akan berdampak pada Kepatuhan Wajib Pajak dalam membayar pajak kendaraan bermotor. Oleh karena itu, Petugas Kantor Samsat Kota Bengkulu harus berupaya mengembangkan kemampuan dan kreativitasnya dalam memberikan pelayanan kepada masyarakat.Tujuan penelitian ini, adalah untuk mengetahui pengaruh pelayanan pajak kendaraan bermotor terhadap kepuasan wajib pajak di kantor SAMSAT Kota Bengkulu. Jenis penelitian ini adalah penelitian deskriptif kualitatif, dengan teknik pengumpulan data yang digunakan yaitu observasi dan kuisioner. Teknik analisis data yang digunakan yaitu metode analisis deskriptif kuantitatif.Hasil penelitian menunjukan bahwa dari regresi linier sederhana menunjukan kepuasan wajib pajak $(\mathrm{Y})=4,838+0.921 \mathrm{X}$. Nilai konstanta sebesar 4,838 artinya jika tidak ada pelayanan pajak sebesar nol (0), maka kepuasan wajib pajak nilainya sebesar 4,838. Sedangkan koefisien regresi pelayanan pajak sebesar 0.921 artinya jika pelayanan pajak naik 1\%, maka kepuasan wajib pajak juga akan mengalami kenaikan atau peningkatan sebesar $5.759 \%(4,838+0.921)$

\section{ABSTRACT}

The purpose of this study was to determine the effect of motor vehicle tax services on taxpayer satisfaction at the Bengkulu City SAMSAT office. This type of research is descriptive qualitative research, with data collection techniques used are observation and questionnaires. The data analysis technique used is descriptive quantitative analysis method.The results showed that from simple linear regression showed taxpayer satisfaction $(Y)$ $=4.838+0.921 X$. The constant value of 4.838 means that if there is no tax service of zero (0), then the satisfaction of the taxpayer is 4.838 . While the regression coefficient for tax services is 0.921 , meaning that if tax services increase by $1 \%$, then taxpayer satisfaction will also increase or increase by $5.759 \%(4.838+0.921)$.

\section{PENDAHULUAN}

Pajak Kendaraan Bermotor merupakan salah satu primadona dalam membiayai pembangunan daerah provinsi. Peningkatan kualitas dan kuantitas pelayanan yang berdampak pada peningkatan kepuasan Wajib Kendaraan Bermotor sehingga diharapkan berdampak pada kepatuhan 
Wajib Pajak dalam membayar atau melunasi kewajiban perpajakankendaraan bermotornya. Kantor Sistem Pelanyanan Satu Atap (SAMSAT) Kota Bengkulu merupakan salah satu instansi pemerintah yang memberikan pelayanan kepada publik/masyarakat yang berkaitan dengan pembayaran pajak kendaraan bermotor. Pada hakekatnya pelayanan Samsat Kota Bengkulu bertujuan untuk memberikan kepuasan masyarakat sebagai pengguna pelayanan. Samsat Kota Bengkulu harus mampu melayani masyarakat secara maksimal daripenyelenggaraan pelayanan, kinerja aparat, dan mekanisme kerja yang ada. Selain itu kepuasan masyarakat sebagai wajib pajak merupakan hal yang sangat penting untuk diperhatikan aparat pajak. Pada hakekatnya pelayanan Samsat Kota Bengkulu bertujuan untuk memberikan kepuasan masyarakat sebagai pengguna pelayanan. Samsat Kota Bengkulu harus mampu melayani masyarakat secara maksimal dari penyelenggaraan pelayanan, kinerja aparat, dan mekanisme kerja yang ada. Selain itu kepuasan masyarakat sebagai wajib pajak merupakan hal yang sangat penting untuk diperhatikan aparat pajak.

\section{LANDASAN TEORI}

\section{Pajak}

Mardiasmo (2016:3) Pajak merupakan iuran yang dibayarkan oleh rakyat kepada negara yang masuk dalam kas negara yang melaksanakan pada undang-undang serta pelaksanaannya dapat dipaksakan tanpa adanya balas jasa. Mardiasmo (2016:3). Iuran tersebut digunakan oleh negara untuk melakukan pembayaran atas kepentingan umum. Untuk melakukan pembayaran atas kepentingan umum. Prof. Dr. Rochmat Soemitro, SH, dalam buku Perpajakan Edisi Revisi (2013:1) menjelaskan Pajak adalah iuran rakyat kepada kas Negara berdasarkan undang-undang (ypemerintah, yang bila dari pemasukannya masih terdapat surplus, dipergunakan untuk membayar publik investment. Siregar (2012:7). Pelayanan yang baik adalah sebuah keharusan yang harus dilakukan oleh Negara kepada masyarakat yang telah ikut berpartisipasi dalam kegiatan membangun Negara melalui pembayaran pajak.Rangkuti dalam Silalahi (2014:22) menyebutkan pelayanan adalah merupakan pemberian suatu kinerja atau tindakan kasat mata dari satu pihak kepada pihak lain.

Thomas Sumarsan (2017:9) adalah sebagai berikut:Wajib pajak adalah orang pribadi ataupun badan, meliputi pembayaran pajak, pemotongan pajak, dan pemungutan pajak yang mempunyai hak dan kewajiban perpajakan sesuai dengan ketentuan peraturan perundangundangan perpajakan. Siti Kurnia Rahayu (2017:273) adalah sebagai berikut: “Orang pribadi atau badan yang memenuhi syarat objektif, yaitu untuk Wajib Pajak Dalam Negeri memperoleh atau menerima penghasilan yang melebihi PTKP (Penghasilan Tidak Kena Pajak), dan jika Wajib Pajak Luar Negeri, menerima penghasilan dari sumber-sumber yang ada di Indonesia yang tidak ada batas minimumnya (PTKP). Diana Sari (2016:178) adalah sebagai berikut : "Wajib pajak adalah pihak yang berdasarkan ketentuan peraturan perundang pundangan perpajakan untuk melaksanakan kewajiban perpajakan." Berdasarkan pendapat beberapa para ahli diatas dapat dikatakan bahwa jumlah wajib pajak adalah orang pribadi atau badan yang mempunyai hak dan kewajiban perpajakan sesuai dengan ketentuan peraturan perundang-undangan. Adapun indikator variabel kepuasan wajib pajak menurut Nadeak (2012:17) adalah sebagai berikut: 1) Timeliness (ketepatan waktu), Timeliness adalah kepuasan pengguna dari sisi ketepatan waktu sistem dalam menyajikan ang dapat dipaksakan) dengan tiada mendapat jasa timbul (kontraprestasi) yang langsung dapat ditunjukkan dan digunakan untuk membayar pengeluaran umum.

Agung (2014:16) bahwa pajak memiliki ciri-ciri diantaranya:Pajak dipungut berdasarkan undang-undang serta pelaksanaannya yang sifatnya dapat dipaksakan.Dalam membayar pajak tidak dapat ditunjukkan adanya kontraprestasi secara langsung oleh pemerintah.Pajak dipungut oleh Negara baik pemerintah pusat maupun pemerintah daerah. Pajak diperuntukkan bagi pengeluaranpengeluaran. 


\section{METODE PENELITIAN}

\section{Metode Analisis}

Metode analisis pada penelitian ini adalah: 1) Analisis deskriptif digunakan untuk memproleh gambaran tanggapan responden sesuai dengan variabel yang diteliti yaitu bagaimana pengaruh pelayanan pajak kendaraan bermotor terhadap kepuasaan wajib pajak. 2) Analisis kuantitatif adalah adalah metode yang mengunakan perhitungan stastistik pada penelitian ini mengunakan bantuan aplikasi statistika SPSS v. 25.

$$
Y=a+b X
$$

Keterangan:

a : Konstanta

$\mathrm{b}:$ Koefisien Korelasi

$Y$ : Nilai Perkiraan (Proyeksi)

$X$ : Periode Waktu

\section{HASIL DAN PEMBAHASAN}

\section{Pembahasan}

Hasil perhitungan $r$ hitung kemudian dikonsultasikan dengan $r$ tabel dengan tarap signifikan 0.05. Apabilah $r$ hitung $>r$ tabel maka butir instrumen dapat dikatakan valid, akan tetapi jika $r$ hitung $<r$ tabel maka dikatakan bahwa instrumen tersebut tidak valid. Uji validitas digunakan dengan cara menguji korelasi antara skor item dengan skor total masing-masing variabel. Secara statistik angka korelasi yang diproleh harus dibandingkan dalam angka tabel $r$ person correlation. Apabila nilai $r$ hitung > $r$ tabel, maka instrumen tersebut tidak valid. 2) Reliabilitas, reliabilitas menunjuk pada satu pengertian bahwa suatu instrumen cukup dapat dipercaya untuk digunakan sebagai alat pengumpul data karena instrumen tersebut cukup baik Suharsini, (2016: 178). Intrumen dikatakan reliabeladalah jika jawaban seseorag terhadap pertanyaan adalah kunsisten atau setabil dari waktu ke waktu dan suatu variabel dikatakan reliabel jika memberi nilai cronbach's alfa>0.60 Ghozali, (2017: 45). 3) Analisis Regresi Linier Sederhana, metode ini digunakan untuk mengetahi pengaruh antara variabel bebas $(X)$ yaitu Pelayanan Pajak dan variabel terikat $(Y)$ yaitu Kepuasan Masyarakat. Persamaan umum regresi linier sederhana antara lain:Y= a + BxHasil penelitian menunjukan bahwa dari regresi linier sederhana menunjukan kepuasan wajib pajak $(Y)=4,838+0.921 X$. Nilai konstanta sebesar 4,838 artinya jika tidak ada pelayanan pajak sebesar nol (0), maka kepuasan wajib pajak nilainya sebesar 4,838. Sedangkan koefisien regresi pelayanan pajak sebesar 0.921 artinya jika pelayanan pajak naik 1\%, maka kepuasan wajib pajak juga akan mengalami kenaikan atau peningkatan sebesar $5.759 \%(4,838$ +0.921 ).

Siregar (2012:7) mengatakan bahwa pelayanan yang baik adalah sebuah keharusan yang harus dilakukan oleh Negara kepada masyarakat yang telah ikut berpartisipasi dalam kegiatan membangun Negara melalui pembayaran pajak. Sejalan dengan penelitian ini bahwa masyarakat perlu mendapatkan apresiasi terhadap kesediaannya tersebut dengan memberikan pelayanan sebagai timbal balik atas respon positif yang telah dilakukan Negara dalam memberikan pelayanan kepada masyarakat diharapkan dapat membantu masyarakat dalam pelaksanaan kegiatan kewajiban perpajakan.

\section{KESIMPULAN DAN SARAN}

\section{Kesimpulan}

1. Pelayanan pajak mempunyai pengaruh positif terhadap kepuasan wajib pajak yang melakukan pembayaran pajak kendaraan bermotor. Dugaan ini dapat diterima karena nilai t hitung lebih 
besar dari t tabel. Hasil uji hipotesa menunjukan bahwa t hitung sebesar $50.270>t$ tabel 1,660. T hitung > t tabel maka kesimulannya menerima hipotesa.

2. Hasil dari regresi linier sederhana menunjukan kepuasan wajib pajak $(Y)=4,838+0.921 X$. Nilai konstanta sebesar 4,838 artinya jika tidak ada pelayanan pajak sebesar nol (0), maka kepuasan wajib pajak nilainya sebesar 4,838. Sedangkan koefisien regresi pelayanan pajak sebesar 0.921 artinya jika pelayanan pajak naik $1 \%$, maka kepuasan wajib pajak juga akan mengalami kenaikan atau peningkatan sebesar $5.759 \%(4,838+0.921)$.

3. Koefisien bernilai positif $(+)$ artinya terjadi hubungan positif antara pelayanan pajak dengan kepuasan wajib pajak, semakin tinggi pelayanan pajak yang diberikan oleh kantor SAMSAT kota Bengkulu maka akan meningkatkan kepuasan wajib pajak yang datang dan membayar pajak disana. Maka dapat disimpulkan bahwa pelayanan yang diberikan dalam membayar pajak berpengaruh secara signifikan terhadap kepuasan wajib pajak.

\section{Saran}

1. Agar dapat memberikan tingkat kepuasan yang lebih tinggi lagi maka pihak Samsat kota Bengkulu harus memperhatikan faktor diluar pelayanan, misalnya faktor lain seperti fasilitas parkir yang luas sehingga kendaraan dapat terjaga dengan aman.

2. Bagi peneliti selanjutnya dapat menambahkan variabel indevenden lainya diluar variabel pelayanan, seperti variabel indevenden lainya diluar variabel pelayanan,seperti variabel fasilitas.

3. Hasil penelitian ini bisa dijadikan masukan dan menentukan kebijakan untuk menyusun strategi untuk lebih meningkatkan kepuasan terhadap pelayanan.

\section{DAFTAR PUSTAKA}

Agung, Mulyo. 2014. Perpajakan Indonesia. Jakarta: Lentera Ilmu Cendekia.

Angestoeti dan Setiawan, 2016. “Pengaruh Kewajiban Moral, Kualitas Pelayanan, Sanksi Perpajakan Pada Kepatuhan Wajib Pajak Di KPP Badung Utara". E-Journal Akuntansi Universitas Udayana Vol.17.2, 913- 937.

Beti Betriani. 2020. "Pengaruh Kesadaran Wajib Pajak Terhadap Penerimaan Pajak Daerah Pada

Badan Keuangan Daerah Kabupaten Kaur". Jurnal Program Studi Manajemen Universitas Dehasen.

Diana Sari. 2016. Konsep Dasar Perpajakan. Bandung: Refika Aditama.

Ghozali, Imam. 2017. Model Persamaan Struktural Konsep Dan Aplikasi Dengan Program AMOS 24.

Semarang: Badan Penerbit Universitas Diponegoro.

Karona Cahya Susena, Suwarni, dan Joko Widianto. 2018. “Hubungan Self Assesment System Dengan

Tingkat Kepatuhan Wajib Pajak Pada Kantor Pelayanan Pajak Pratama Argamakmur Provinsi

Bengkulu". Jurnal Program Studi Manajemen Fakultas Ekonomi Universitas Dehasen Bengkulu. Mardiasmo. 2016. Perpajakan Edisi Revisi Tahun 2016. Yogyakarta: Penerbit Andi.

Nadeak, Reanuli. 2012. "Pengaruh Kualitas Sistem E-Registration terhadap Kepuasan Pengguna dan Kepatuhan Wajib Pajak di Kantor Pelayanan Pajak (KPP) Pratama Cimahi". Bandung: Universitas Sahid.

Rangkuti (2014:22) Rangkuti, Freddy. 2014. Analisis SWOT Teknik Membedah Kasus Bisnis. Jakarta : Penerbit PT. Gramedia Pustaka Utama.

Siregar Anita Yuli dkk. 2012. "Pengaruh Pelayanan Fiskus dan Pengetahuan Perpajakan terhadap Kepatuhan Wajib Pajak (Studi Empiris terhadap Wajib Pajak di Siti Resmi, 2014. Perpajakan Teori dan Kasus Edisi 8-Buku 1. Salemba Empat. Jakarta 
Semarang Tengah)". Jurnal IImu Administrasi Bisnis. Universitas Diponegoro.

Sugiyono (2017:93) Sugiyono. (2017). Metode Penelitian Kuantitatif, Kualitatif, dan R\&D. Bandung : Alfabeta, CV.

Suharsimi Arikunto. 2016. Prosedur Penelitian: Suatu Pendekatan Praktik. Jakarta: Rineka Cipta.

Siti Kurnia Rahayu. 2017. Perpajakan Konsep dan Aspek Formal, Bandung: Rekayasa Sains.

Thomas Sumarsan. 2017. Perpajakan Indonesia Edisi Kelima. Jakarta: Indeks.

Undang-Undang No 25 tahun 2009 tentang Pelayanan Publik.

UU Nomor 28 Thaun 2007 tentang ketentuan umum dan tata cara perpajakan (perubahan ketiga UU 6 Thun 1983)..

114 | Atika Puspita Sari, Karona Cahya Susena, Rinto Noviantoro; Effect of Motivation and Job... 